\title{
IDENTITY OF KAUNAS INHABITANTS: MEMORIES OF THREE GENERATIONS
}

\author{
KARINA RAČAITYTE் \\ Doctoral student (ethnology), Vytautas Magnus University \\ E-mail: karina.racaityte@gmail.com
}

\begin{abstract}
The aim of this paper is to determine the identity of three generations of Kaunas inhabitants. Kaunas is the second biggest city in Lithuania. During the Soviet occupation, new districts such as Dainava, Kalniečiai, Eiguliai and Šilainiai were built. This paper is based on A. Assmann's theoretical approach to communicative memory. Empirical material was collected using field research methods: in-depth, semi-structured interviews. 115 narratives were analysed, employing comparative, retrospective, narrative analysis methods. The results of this research suggest that narratives of communicative memory can help to create cultural identity related to specific urban places or the ones displaced from these places.
\end{abstract}

Keywords: communicative memory, cultural identity, identity, narratives, generational memory.

\section{INTRODUCTION}

After the Second World War, the number of inhabitants of Kaunas city started to grow with the development of the industry. New employees of industrial companies had to be settled in the locations of production. Therefore, new neighbourhoods of Kaunas were designed and their construction started in the 1960s. The neighbourhoods of Dainava, Kalniečiai, Eiguliai, Šilainiai were different from the historic neighbourhoods of Kaunas city in that they were built in mostly empty spaces: in the fields or territories of former villages or settlements in the suburbs. Very little trace of 
old inhabitants remained in the new neighbourhoods, since the majority of people moved out from the villages, their buildings were demolished. In 2019, 144281 permanent inhabitants, i.e., 50.31\% of all inhabitants of Kaunas (in the beginning of 2020, 289380 permanent inhabitants were living in Kaunas city $)^{1}$ lived in the districts of Dainava, Kalniečiai, Eiguliai of Kaunas city. The inhabitants of these neighbourhoods encountered social and cultural problems, such as uncertain identity, memories related to traumatic experiences present at all levels of memory (individual, communicative, cultural memory). Analysing the narratives of people from Kaunas, it was noticed that respondents who were of a similar age had coincident memories, their narratives had kindred features of structure and content. This paper addresses the following problem: how the individual, communicative and cultural memory is reflected in the narratives of the inhabitants of Kaunas? Can those narratives be "used" for construction of the identity of a respondent? The object of the research are the narratives of the inhabitants from Dainava, Kalniečiai, Eiguliai, Šilainiai districts of Kaunas city. The aim is to establish the identities of three generations of Kaunas inhabitants. In order to achieve the aim, the following goals were set for the current study: to analyse the narratives of the inhabitants of Kaunas and to determine their characteristic features; to distinguish narratives that belong to the level of communicative memory; to establish how these narratives are used by respondents to construct their identities. Although the field of this study was comprised of four selected Kaunas microdistricts, the analysis of the ethnographic research material revealed that there were no significant or critical differences between stories of the residents from these four Kaunas districts. However, differences emerged between the stories of respondents from different age groups. Results of the study showed that respondents chose different methods to construct their identities, and their identities were not just urban. These identities could be various, related to parts of the city or displacement from the city, pertaining to lifestyle or the place of origin. Therefore, the study aims to establish the identity of three generations of Kaunas residents, which is a broader concept than urban identity.

This paper is based on the analysis of ethnographic fieldwork material. Ethnographic material was collected in 4 districts of Kaunas - Dainava, Eiguliai, Kalniečiai, Šilainiai - in 2017-2020, using an ethnographic questionnaire "Changes of urban identity of the inhabitants of Kaunas in the middle of the $20^{\text {th }}$ century - the beginning of the $21^{\text {st }}$ century" prepared by the author of this paper. In order to reflect the cultural environment and

${ }^{1}$ The Lithuanian Department of Statistics, portal of official statistics. Available at: https://osp.stat.gov.lt/infografikas-kaunas-2020 (last viewed July 15, 2020). 
the variety of people living in the districts, no special criteria regarding the ethnicity or social status were put forth before the research; however, criterion of age was applied (only those older than 18 were interviewed). The respondents were born from 1930 to 1996.115 respondents who were born in Kaunas or had moved to Kaunas from smaller towns, were interviewed by the method of in-depth interview and semi-structured interview. 69 respondents were female, 46 respondents - male. 21 respondents had acquired secondary education, 8 had special secondary (vocational) education, 22 had higher education, 63 had university education. Empirical material was analysed using comparative and retrospective methods. The excerpts of interviews presented in this paper have not been edited, so as to reveal the authenticity and style of their speech. Narrative and narrative analysis terminology is used in the article. The narrative is understood as a logically structured sequence of events pertaining to a particular story (Hawthorn 1998, 209). Narrative analysis is a research strategy which puts forth that when specific stories are told, they provide insights into the experiences of the people (Bitinas, Rupšienè, Žydžiūnaitè 2008, 303).

While analysing the narratives of the respondents during interviews, certain patterns were noticed within the narratives of certain age groups. Narrative analysis showed that even individuals from different age groups could have similar experiences relating to the general time period, as their everyday lives at the time shared common themes. Memorable events (in the world, country, city, district or personal life) also form a part of their memory. According to the theory of Karl Mannheim, socio-political events have the greatest influence and cause the biggest impact on an individual at the age of 12 to 22 . This creates generations with different experiences of their childhood and teenagehood (Mannheim 1952). A generation is not a homogeneous group: people who belong to the generation can have different education, belong to different social classes. Not every generation shares a consciousness or identity belonging to their generation (Mannheim 1952). The problem of generational barriers and their definition is relevant and still discussed in theoretical scientific literature. Sociologists use the term of cohort generation in order to describe the groups of people who belong to different age groups. Cohort generation is a group of the same or similar age, connected by mutual historical experiences, on the basis of which a specific mentality of the group is formed, distinct from other similar groups (Miller 2000, 30). According to S. Kraniauskiene, an individual identity "[..] is understood in social theory as a unique and authentic self-awareness acquired by an individual" (Kraniauskiene 2004, 41). It is important to emphasize that both individual and collective identities are formed in communication with others (family members, neighbours, classmates or colleagues), thus, a person 
re-establishes his identity. This paper claims that in the present postmodern world an individual can have more than one identity. These identities can be both equally expressed and important or have differing levels of importance to the respondent.

The theoretical approach of memory by J. and A. Assmann is applied in the article (Assmann 2008). J. Assmann singles out three types of memory: individual, communicative and cultural that can be reflected in the narratives. According to A. Assmann, "communicative memory is formed through regular conversation with other people and through common experience. [..] Communicative memory embraces a period of 80-100 years, i.e., three to five generations" (Assmann 2013, 43-44). The author of this article refers to generational cohorts according to K. Joesalu (Joesalu 2017), and adds a new generational cohort based on the current research those born during the restoration of independence. K. Joesalu analysed narratives of different generations in Estonia and distinguished three generations that lived during the Soviet era: those who were born in the 1920s, 1940s and 1970s (Joesalu 2017). She also examined the narrated experiences of different generations from a theoretical point of view, based on J. and A. Assmann and K. Manheim. This paper does not discuss respondents who were born in the 1920s because the number of their interviews is small, not many members of this group have survived.

Sociologists, ethnologists and political scientists studied the communicative and cultural memory narratives in Lithuania and their influence on the processes of identity formation. I. Šutiniene has studied the peculiarities of Soviet-period collective memory traits forming in modern society (Šutinienè 2003), questions of social memory, connections of biographical narratives and identity in the late modern society (Šutiniene 2008, 111). L. Vervečkienè analysed the Soviet narratives of three generations - grandparents, parents and grandchildren - looking for a "generational gap" and its traits (Vervečkienè 2019). D. Leinartè studied how the members of various generations remember the Soviet period (Leinartè, Žilinskienè, Kraniauskienė, Šutinienė, Gečienė 2014). L. Žilinskienė analysed the memories from the intergenerational aspect (Žilinskienè 2015, Žilinskienè, Kraniauskienè, Šutinienè 2016). R. Račiūnaitė-Paužuolienè and G. Matusevičienè examined the narratives of three generations of Lithuanian women in exile, values reflected therein and experiences of repression (Račiūnaitè-Paužuolienè, Matusevičienè 2017, 2018). While discussing memory narratives, it is important to mention the prevailing traumatic experiences. Beyond influencing the lives of the people who suffered from those experiences directly, they also influence their descendants (Vaskelienè, Kazlauskas, Gailienè, Domanskaitè 2011; Gailienè 2008). 


\section{“WE DIDN'T SEE MUCH OF A LIFE": THE FIRST SOVIET GENERATION OR SILENT GENERATION - BORN IN 1940s}

In this group, K. Joesalu includes the people born from the late 1930s until the first half of the 1950s. She quotes Wulf, who describes this group as "post-war children" (2016) (Joesalu 2017, 34). This generation of respondents was distinguished and defined according to the features of narratives characteristic to the members of this age group, the content and form of narratives. The age and historical events reflected in their memories are amongst the main criteria that enable distinguishing of the respondents who belong to this age group. They were born in the interwar period before the $2^{\text {nd }}$ World War, during the war, or after it. Difficulties and painful experiences, also living conditions after the war are vividly reflected in their memories. This historical period was characterised by the threatening circumstances and corresponding living conditions. Researchers who analysed the narratives of women - survivors of exile, noticed that common experiences shared during the after-war period united respondents of different ages: "[..] the difference in women's age did not have any influence on the identity of exiles. All respondents shared similar experiences suffered in exile" (Račiūnaitè-Paužuolienė, Matusevičienė 2017, 258).

A woman, who was born in historical Žaliakalnis district in 1937 and later lived in the district of Dainava, describes life after the war:

"It was a post-war period [..] it was very difficult for everyone, [..] all the neighbours, how to say, lived like a family: we shared what we had despite the fact that everyone was afraid of each other. To some extent, people were afraid of being reported until 1951, 1954 probably [..] From about 1960s, people, youth actually started to recover. Those factories opened up [..]. There was more work [..]" (VDU ER 2669/9).

Close relationship of assistance among the neighbours partly compensated insecurity which prevailed during the interwar period. However, one could not feel safe even around these people. More than one identity is exposed in the memories of the respondent. In the narrative the woman constructs her identity through obvious, measured criteria and criteria treated as "objective" such as the place of birth, the origin of her parents and grandparents:

"[I $\mathrm{am}]$ an inhabitant of Kaunas, a Lithuanian, and an inhabitant of Žaliakalnis, since Žaliakalnis is both my native place and home. Everything in one place. Actually, my mother and my grandparents are practically from Kaunas. [..] I just know as little as this. I do not know any surnames of my great grandparents, nothing. Somehow, I'll say it like this, we lived in a generation where everything was suppressed. [..] Survival was all that mattered. [..] My mother was just fifteen years old when her parents died. I have, definitely, asked my mother about them but she never told anything 
and I don't even know why. Sometimes I thought that we didn't know how to talk openly, so she could tell" (VDU ER 2669/9).

During the Soviet era the history of the relatives, their origin was not bravely spoken of in families. It was not spoken of because, according to the respondent, there were more important concerns: "to survive, live". Also, an assumption can be made that the mother of the respondent did not talk with her daughter about her parents who died early, because those themes were painful, sad and unpleasant. In order to discuss those themes, one needed to confront the pain and things that were hidden even from the closest members of the family. Ethnologists, who examined the narratives of lives of women in exile who had suffered traumatic experiences, noticed that those experiences "had negative impacts on those women's personalities: led women to closedness, formed a complex of inferiority" (Račiūnaitė-Paužuolienè, Matusevičienè 2018, 300). The impact of traumatic experiences on personality and the environment which restricted the ways to express thoughts - a combination of those two factors was the cause why the respondents of this generation were not willing to speak about their experiences.

During the analysis of the narratives of respondents, it was noticed that memories of difficulties, dangers, insecurity and the aim to survive prevailed both on the level of individual and communicative memory. Specific individual and collective identities were formed concerning repressions of totalitarian rule, as well as missed childhood and teenage years (specific to certain areas), place of birth, place of residence or origin of the families.

\section{THE LAST SOVIET GENERATION - BORN IN THE 1970S}

According to K. Joesalu, these respondents were born in the years of late socialism, most of them acquired an education in the Soviet system, those born at the beginning of the decade already started their work life in the late 1980s. Their coming of age coincided with great structural changes in society [..]. In the new society that had opened up, there were, on the one hand, several new opportunities to shape one's life trajectories, while, on the other hand, social structures supporting their entry into adulthood were missing. (Joesalu 2017, 35) The most significant historical events for these respondents were the freedom of movement and the restoration of independence. As young adults, these people underwent the social, cultural, and economic changes that took place after 1990.

The second generation, which was defined during analysis of narratives reflecting respondents' memories, was born during the mature Socialism period. This generation has been singled out and selected according to the 
features of the content and structure of their narratives that are analysed in this section. Their parents were suspicious, cautious and practical people, the main goal during the post-war period was to survive. These respondents were born during the period of political and economic thaw which started in the Soviet Union after the death of J. Stalin. When they grew up, more opportunities to study and travel in the Soviet Union emerged. Although sparse, cultural news from the Western world, such as rock and jazz music, Western magazines, fashion trends, ideas and lifestyle of the hippie subculture reached the members of this generation. The Western world was appealing, although it could not be reached easily. For some people, the interest in Western culture was a specific form of cultural resistance. According to E. Ramanauskaitè, who researched alternative movements popular among the youth in the second half of the $20^{\text {th }}$ century, "The Western youth trends came with music. In terms of anthropology, it is the consequence of enculturation." (Ramanauskaitè 2003, 141) E. Ramanauskaitè refers to J. Kristeva and states that at that time youth "rebelled against authorities, political parties, institution, social coercion and against monopolisation of cultural taste, against "parents' culture"" (J. Kristeva 2002, quoted from Ramanauskaite 2003, 129). Of course, not all the teenagers and young people who lived at that time were interested in the alternative culture, not everyone listened to rock music, wore long hair or participated in the resistance movement. However, even those, who did not participate in the activities directly could feel more freedom in public space.

During the interviews, Soviet ideology prevailed at the levels of personal memories (especially pleasant childhood memories, leisure activities with the friends), also in the layers of memories related to historical era. These respondents were talking more about their friends, leisure and hobbies, the theme of hard work and suffering being less common. This could be the result of a certain economic stability and the common narratives of progress.

A woman born in 1958, who lived in her own house in Šilainiai district, told the interviewer that her whole life went on in the city centre and that she came back home for only to rest. She emphasized her aim to be free, independent.

"[..] I would single out the period when I became a student. All the horizons opened to me then, when I became a free person. [..] I didn't like school [..]. I saw it as a prison of prisons and didn't like it at all. [..] [while studying in the university] nobody persecuted, controlled, and that was the most important thing to me. [..] I received a scholarship of 40 roubles and nobody took the money from me, I could do what I wanted with it (VDU ER 2669/6).

Another respondent (woman born in 1974 and living in the Dainava district) highlights the duality of her identity. According to her, she is 
perceived as an inhabitant of a city by the local villagers, while being a villager in the eyes of the city people. Some of these respondents called themselves the citizens of the world, they did not want to relate themselves to some specific geographical place. As most of their parents, the respondents from this age group also have memories about traumatic life experiences, duality of Soviet life. The respondents who had arrived to Kaunas from smaller towns and villages or who had close relatives that were not from Kaunas, can also have a bicultural identity.

\section{BORN DURING THE RESTORATION OF INDEPENDENCE}

This generation has been defined without referring to K. Joesalu's generational cohorts. Changes in lifestyle in independent Lithuania were reflected in the content of their narratives. The majority of respondents are living in the districts since their birth. During the analysis of the narratives of the members of this generation, also in order to distinguish them from other narratives, it was noticed that "the boundaries of generations" were not completely clear. Even the older respondents who were born at the beginning of 1980s could have some features of this generation. The respondents of this generation were born approximately in 1980-1996. During their life, they have seen the most important historical events - the Restoration of Independence of Lithuania or lived after these events. During their early lives, they already inhabited a different political and economic system, had free media and non-ideologized education, an entirely different environment than the one of their parents. The narratives from the level of individual memories are common to respondents. There are less or even no narratives about the Soviet era. It is important to notice that those changes are not always verbalized, not always expressed as a contrast to previous or future times.

Images of personal life prevail in the 28-year-old man's narratives about life in the Kalniečiai district from his very birth in 1992. In the narratives, he emphasized the relationship between people, accidents in the district, daily life: "The best things that I remember are when you didn't say "bye" to your friends and said "see you tomorrow" because you knew you will see them tomorrow [..]. 1990 and 2000, 2001 was a period when we were not grown up yet and the neighbourhood was very important for us. The territories were divided in our childhood. Those who lived in Kalniečiai could not go to Eiguliai and vice versa. And grownups were very busy: work, work, always took care of children, collected from kindergarten, but I didn't see life of a grown up at that period of my early life" (VDU ER 2669/107).

It seems that active participation in the social life of the district; childhood which was spent in the neighbourhood helped to create an identity 
related to his place of residence for this respondent. The respondent considers himself to be an inhabitant of Kaunas, as well as a part of the district: "Yet, by all means, I am the creator of my living place. I like living here, I like being here rather than anywhere else. I know that I will live in this district in the future, either in my own house or a flat. First of all, I am a part of the district [..] I also consider myself to be an inhabitant of Kaunas" (VDU ER 2669/107).

The respondents called themselves Lithuanians, inhabitants of Kaunas, also considered themselves a part of the district. Some of these respondents did not want to relate themselves to some specific geographical place. These respondents could have a displaced and/or bicultural identity. During the analysis of the narratives of respondents, it was noticed that both in the level of individual memory and in the communicative memory, the memories of an individual level of life in the district and communication with others prevail. Respondents who had spent their childhood and teenage years in the same district often tended to link their identity with the district they lived in.

\section{CONCLUSIONS}

Analysis of the fieldwork material revealed that the narratives of respondents from different age groups had different features in both form and content. Having analysed the narratives, it was concluded that the "boundaries" of a generation should be described according to the sets of memories existing at the levels of communicative and cultural memories but not according to the year of birth.

The identity in the narratives of the members of the post-war generation is usually constructed in accordance with "objective" criteria, such as a place of birth and living place, the origin of parents and grandparents, nationality and language. Those identities are common to the second group of respondents, who have been born during the of mature Socialism period. However, this generation is different from their parents since they also have identities related to the memories of individual level and also bi-cultural identities and identities separated from the specific geographical places. The memories that belong to the level of individual memory are common to the narratives of members of the generation of the Restoration of Independence. These respondents are characterized by various types of identities: related to the place of birth or living place, origin, language, nationality, and global identities. It was noticed that those respondents who had spent childhood and teenage years living in one if the districts tended to relate their identity with the district more often. 


\section{SUMMARY}

The aim of the current paper is to determine the identity of three generations of Kaunas inhabitants. Kaunas is the second biggest city in Lithuania. During Soviet occupation, new districts as Dainava, Kalniečiai, Eiguliai and Šilainiai were built. The inhabitants of these neighbourhoods encountered social and cultural problems such as uncertain identity, memories related to traumatic experiences present at all levels of memory (individual, communicative, cultural memory). Having analysed the narratives of people from Kaunas, it was noticed that the respondents who were of a similar age had similar memories, their narratives had coincident features of structure and content.

This paper is based on A. Assmann's theoretical approach to communicative memory. Empirical material was collected in Kaunas using field research methods: interview, in-depth, semi-structured interviews. 115 narratives were analysed, using comparative, retrospective, narrative analysis methods.

Having analysed the narratives, it was concluded that the "boundaries" of a generation should be described according to the sets of memories existing at the levels of communicative and cultural memories but not by year of birth. The respondents from different age groups had similar experiences and shared stories about them with other people from their environment. The results of this research suggest that narratives of communicative memory can help to create cultural identity, related to (or displaced from) certain parts of the city.

\section{SOURCES}

VDU ER - Ethnology Archive of Vytautas Magnus University, Department of Culture studies, B. 2669. Ethnographic material collected by K. Račaityte 2017-2020 in Kaunas.

\section{BIBLIOGRAPHY}

Assmann, J., 2008. Communicative and Cultural Memory. Cultural Memory Studies: An International and Interdisciplinary Handbook. Berlin, New York.

Assmann, A., 2013. Między historią a pamięcią: antologia. Warszawa: Wydawnictwa UW. 2013.

Bitinas, B., Rupšienè, L., Žydžiūnaitè, V., 2008. Kokybinių tyrimu metodologija, Klaipèda: S. Jokudžio leidykla.

Gailienè, D., 2008. Ka jie mums padarè? Lietuvos gyvenimas traumu psichologijos žvilgsniu. Vilnius: Tyto alba.

Hawthorn, J., 1998. Moderniosios literatūros teorijos žinynas. Vilnius: Tyto alba.

Jenkins, R., 1996. Social Identity. London: Routledge. 
Joesalu, K., 2017. Dynamics and Tensions of Remembrance in Post-Soviet Estonia: Late Socialism in the Making. Doctoral dissertation. Tartu: University of Tartu Press.

Kraniauskienė, S., 2004. Identiteto tyrimo metmenys: kartų identiteto paieška XX a. lietuvių autobiografijose, Sociologija. Mintis ir veiksmas, 2, 40-52.

Kristeva, J., 2002. Revolt, she said. An interview by Philippe Petit. London: Semiotext(e).

Leinartè, D., 2008. Prijaukintos kasdienybès. Biografiniai Lietuvos moteru interviu, 19451970 m. Vilnius: Vilniaus universiteto leidykla.

Leinartè, D., 2010. Adopting and Remembering Soviet Reality: Life Stories of Lithuanian Women, 1945-1970. Amsterdam, New York: Rodopi/BRIL.

Leinartė, D., Žilinskienė, L., Kraniauskienė, S., Šutinienė, I., Gečienė, I., 2014. Sovietmečio atmintis gyvenimo istorijose. Vilnius: Vilniaus universiteto leidykla.

Mannheim, K., 1952. [orig. 1928] The problem of generations. Essays on the Sociology of Knowledge. NY: Oxford Univ. Press: 276-320.

Miller, R. L., 2000. Researching Life Stories and Family Histories. London: Sage.

Račiūnaitė-Paužuolienè, R., Matusevičienè, G., 2017. The repressive experiences of Lithuanian women deportees in their life histories: the expression of identity and values. Perspectives of Baltic philology III. J. Niewulis-Grablunas, J. Prusinowskiej, J. B. Walkowiak (red.). Poznań, 255-267.

Račiūnaitė-Paužuolienè, R., Matusevičienè, G., 2018. Lietuvių tremtinių moterų vertybès gyvenimo istorijose. LITUANISTICA. 64 (114), 294-302.

Ramanauskaitè, E., 2003. Jaunimo kultūrinè rezistencija sovietmečiu: hipių kultūrinès idejjos Lietuvoje. Kauno istorijos metraštis. 4, 127-163.

Šutinienè, I., 2003. Sovietinio laikotarpio atminties bruožai autobiografiniuose pasakojimuose. Krukauskienè, E., Šutinienè, I., Trinkūnienè, I., Vosyliūtè, A. Socialine atmintis: minejimai ir užmarštys. Vilnius: Eurgimas.

Šutinienė, I., 2008. Socialinė atmintis ir lietuvių tautinè tapatybė. V. Čiubrinskas, J. Kuznecovienè, Lietuviškojo identiteto trajektorijos. Kaunas: Vytauto Didžiojo universitetas.

Šutinienè, I., 2013. Komunikacinè atmintis Lietuvos didžiuosiuose miestuose. Nikžentaitis, A. Atminties daugiasluoksniškumas: miestas, valstybè, regionas. Vilnius: LII leidykla.

Šutinienè, I., 2015. Tautos istorijos pasakojimo raiška daugiakultūrèje aplinkoje: Pietryčių Lietuvos lenkų etninès grupès atvejis. Sociologija. Mintis ir veiksmas. 2015/2(37), 85-105.

Vaskelienè, I., Kazlauskas, E., Gailienė, D., Domanskaitė G. V., 2011. Komunikacija apie patirtas politines represijas šeimoje: tarpgeneracinis aspektas. International Journal of Psychology: A Biopsychosocial Approach / Tarptautinis psichologijos žurnalas: biopsichosocialinis požiüris. 9, 91-104.

Vervečkienè, L., 2019. Pabrèžta, nutylèta, pateisinta: „kartų efektas“ senelių, tėvų ir anūkų sovietmečio atmintyje. Politologija. 4 (96). 8-37.

Wulf, H., 2016. Shadowlands. Memory and History in Post-Soviet Estonia. London, New York: Berghahn.

Žilinskienè, L., 2015. Šeimos atmintis. I. Juozeliūnienė, J. Seymour. Šeiminiai pokyčiai atviru Europos sienu ir globalaus mobilumo akivaizdoje: resursai, procesai ir praktikos. Vilnius: Vilniaus universitetas.

Žilinskienè, L., Kraniauskienė, S., Šutinienè, I., 2016. Gimę socializme: pirmoji sovietmečio karta. Vilnius: Vilniaus universiteto leidykla. 


\title{
KAUṆAS IEDZĪVOTĀJU IDENTITĀTE: TRĪS PAAUDŽU ATMIṆAS
}

\author{
KARINA RAČAITĪTE \\ Vītauta Dižā Universitātes (Kauṇa) doktorante \\ E-pasts: karina.racaityte@gmail.com
}

\section{KOPSAVILKUMS}

Šĩ raksta mērkis ir noskaidrot trīs paaudžu Kauņas iedzīvotāju identitāti. Kauña ir otrā lielākā Lietuvas pilsēta. Padomju okupācijas laikā tika uzcelti jauni rajoni - Dainava (Dainava), Kalnieči (Kalniečiai), Eiguḷi (Eiguliai) un Šilaiņi (Šilainiai). Šo rajonu iedzīvotājus skar gan sociālas, gan kultūras problēmas: neskaidra identitāte un ar traumatisku pagātnes pieredzi saistītas atminnas visos atmiņu līmeņos (individuālajā, komunicētajā un kultūratminnas). Analizējot Kauņas iedzīvotāju stāstus, ir redzams, ka līdzīga vecuma respondentiem ir līdzīgas atminas, viņu stāstos ir līdzīgi atsevišḳi strukturāli un satura elementi.

Šis raksts ir balstīts Aleīdas Asmanes teorētiskajā pieejā kultūratminai. Empīriskais materiāls ticis savākts Kauņā, izmantojot šādas lauka pētījuma metodes: intervijas, padziḷinātas un daḷeji strukturētas intervijas. Ar salīdzinošās, retrospektīvās un naratīva analīzes metodes palīdzību analizēti 115 naratīivi.

Naratīvu analīze ḷauj secināt, ka paaudzes "robežas" var definēt kā atminu kopumu, kurš pastāv komunikatīvajā un kultūratmiņas līmenī, bet ne pēc dzimšanas gada. Respondentiem no dažādām vecuma grupām bija līdzīga pieredze un kopīgi stāsti ar citiem viniem tuvā vidē dzīvojošiem cilvēkiem. Šì pētījuma rezultāti norāda, ka kultūratmiņas naratīvi var palīdzēt radīt kulturālu identitāti, kas raksturīga noteiktām pilsētas daḷām. 